(昭和 34 年 9 月 28 日受理)

\title{
繊維および糸の曲げ剛さの測定法
}

\author{
信州大学㿺維学部呉祐吉・篠原昭 \\ 古平善蔵
}

\section{MEASUREMENTS OF THE FLEXURAL RIGIDITY OF FIBER ADN YARN}

\author{
By Yukichi Go, Akira Shinohara and Zenzo Kodaira
}

(Faculty of Textiles, Sinshu University, Ueda, Japan)

The two elastica methods (long column and loop) to measure the flexural rigidity of the fiber and yarn are devised.

In the long column method, a sample of length $l$ is standed perpendicularly and a load larger than its critical one of the buckling is applied to the top (free) end. In measuring the vertical deflection $x_{\alpha}$ ie the interval between a horizontal line and loaded end is measured experimentaly, the flexural rigidity is obtained by the folloing equation :

$$
E I=\frac{P l^{2}}{[\boldsymbol{F}(\alpha, k)]^{2}}
$$

Where ; $\boldsymbol{F}(\alpha, k)$ denominator of perfect elliptical integration of the lst kind, $k=\sin \alpha / 2$ where $\alpha$ is tangent of loaded end of the distorted sample, this $\alpha$ is obtained by the graph (Fig. 3) indicating the relations between $x_{\alpha} / l-k-\boldsymbol{F}(\alpha, k)$. When the sample's own weight is negligible small, this formula is available to the cantilever method loaded at its free end. In this case, it is convenient to obtain $\alpha$ using a graph of $y_{\alpha} / l-k$ (Fig. 2), where $y_{\alpha}$ is the vertical deflection from its initial coordinate and $P \cos \alpha \sin \alpha$ is used replaing $P$. These long column method is applicable only for large deniers of above 20 denier and yields incorrect results at lower deniers.

The loop method is a development from the above method, applicable to more fine filaments. This. principle is reported by D. Sinclare in 1950 (ref. cited No.10). As shown in Fig. 4 \& 5, looped sample is extended verticaley between torsion balance and cathetometer. If the height $a$ from the vertical line between two clamped ends where distance is large enough to neglect the end moment, and loop apex, and tension $T$ are measured experimentally, $E I$ is obtained from the equation:

$$
E I=\frac{a^{2} T}{4}
$$

It is more convenient to make fiber into a bundle to measure finer samples.

In order to measure $E I$ of the fiber bundle, stable ply twist yarn is used, when twisted yarn composed of $m$ filaments is folded, expected stable ply is obtained (Fig. 7). In this case, there are relations denoted in eqs. 1-3 between apparent flexural rigidity of twisted sample $B_{h}$ and $E I$ of a flament, especialy when the twisted angle with fiber axis $(\pi / 2-\theta)$ is very small, i. e. $\theta=90$,

$$
E I=\frac{1+\sin ^{2} \theta}{4 m \sin \theta} B_{h}
$$

The results of $E I$ of a filament from this method is larger than that from the other single yarn method, its value increases as $\theta$ is increased.

(Received September 28, 1959)

\section{1. 緒論}

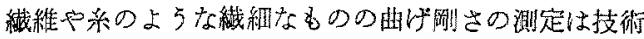
的にむずかしく，三，三の方法が試名られているにすぎ
ない。著者らは織物の成さの研究に和いて原杀ないしは 原䄉維の曲げ用さとの関係を娚べる目的の一環として， それに便利な测定法を考えてみた。 徒来，来むるいは織物類の曲げ岡さ $(E I)$ の測定に用 
いられてきた方法を大別すると，

（1）自重あるいは荷重による微小撓み現象を利用す る๘の。

（2）長柱の挫屈現象を利用するもの

(3) Elastica として取扱 5 もの

(4) Heavy Elastica として取扱 5 bの

（5）動的振動測定に上るもの

以上のごとくなる。（1）は材料力学に括ける梁の撓みの

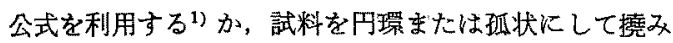
を与克カスチリアノの定理を応用するるの2であり，織 維や杀には必すしも適当な方法ではない。(2)の方法は 桜田・辻両氏により報告されたるので，長柱の挫屈に関 するオイラーの公式を応用し，トーションバランスとカ

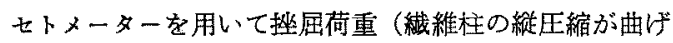
に変わる臨界荷重)を求めるものである。elasticaのうち 最も広く用いられているのは自由端荷重式の片持梁法で ある。これの解析は F.H. Hummel \& W. B. Morton ${ }^{4)}$ K よつて行われたが，他の elastica の場合と同様棈円積分 表を用いれば容易にとくことができるため，比較的多く の応用例が報告されている。この方法の变形として半円 形の筒に一定張力で系を撩きつけ，その撩付き状態から

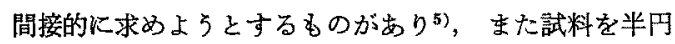
形汇曲げ，そのモーメントを測定し， $E I=-M \rho(M:$ モ 一メント, $\rho$ : 円の半径) の関倸から求める方法6)などが おる。(4) の heavy elastica \& Hummel らの研究 に始まるのであるが，F.T.Peirce $)^{7)}$ につて織物の測定 飞便利な公式が導かれ，さらに W.G. Bickley ${ }^{8}$ に上つ てより精度の高い式が導かれた。ただ heavy elasticaの 方法では糸類のように比較的線密度の小さなものではか えつて不便な場合が多い上うである。最後の動的方法は 振動りード法あるいは附加質量振動りード法9などによ る測定が報告されているが，いまの場合織物との関連性 に主眼を扔くために，これは一心考虑外に和くことにし た。

これらの方法が実際に応用できるのは試料が比較的太 く，しかも静置状熊で真直ぐなものに限られる。したが つて 2 den. 前後のモノフィラメントや挖縮のある羊毛 などには適さないし，束瀻維では生系の上ろに相互に接 触し，無然のものにのみ利用できるにすを゙ない。そこで 系条件を次の 2 つに大別し，それぞれに便利な方法の5 ち，われわれが採用した elastica 法について報告する。

a）集束状態の抱合が悪く，さらに撚のあるもの

b) 比較的太く，真直くで，乙かも然のないもの

本報では便宜上a）応用するものを長柱法，b）のを ループ法と呼ふことにする。

\section{2. 原理および方法}

（i）長柱法：片持梁法を䋐維に応用する場合に，接 みを適当にするような荷重の選択がむずかしく，また辻 氏らの方法では压樎力の印加が細長比 (slenderness ratio）の大きな場合には技術上むずかしい欠点がある。そ こでわれわれはこの欠点を除いて長柱の挫屈後の撓みを 測定し，から同一荷重に対しては水平片持梁上り荷重奻 果を少なくするため，Fig. 1-A のごとき方法を用いた すなわち適当な長さの㵶維の一端に荷重を附し, その撓 みから EI を求めることができる。これは原理的には， F.T. Peirce の方法や水平片持梁法と全く同じあのであ. るが。自重効果が小さいことと, 垂直固定が容易なこと 湘定が办平状の上り簡単である等の長所がある,

いま荷重を $P$, 試長を $l$, 荷重端に甜ける接線と垂直

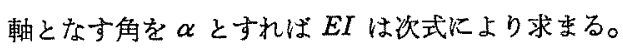

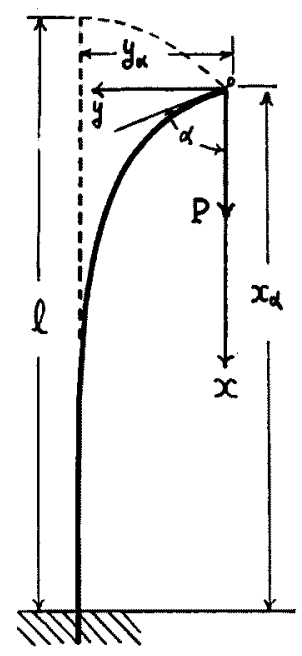

(A) Vertical method

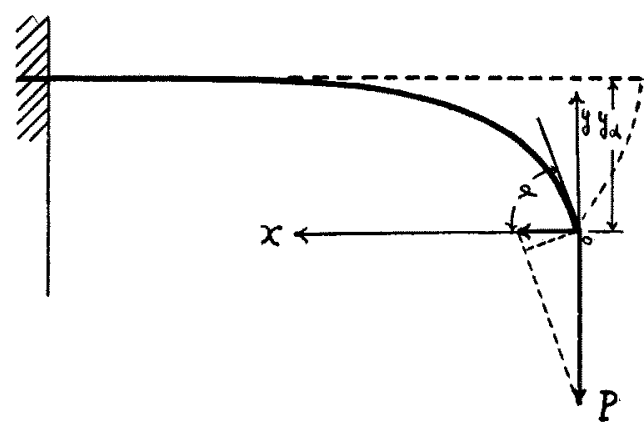

(B) Horizontal method

Fig. 1 Principle showing long column method 


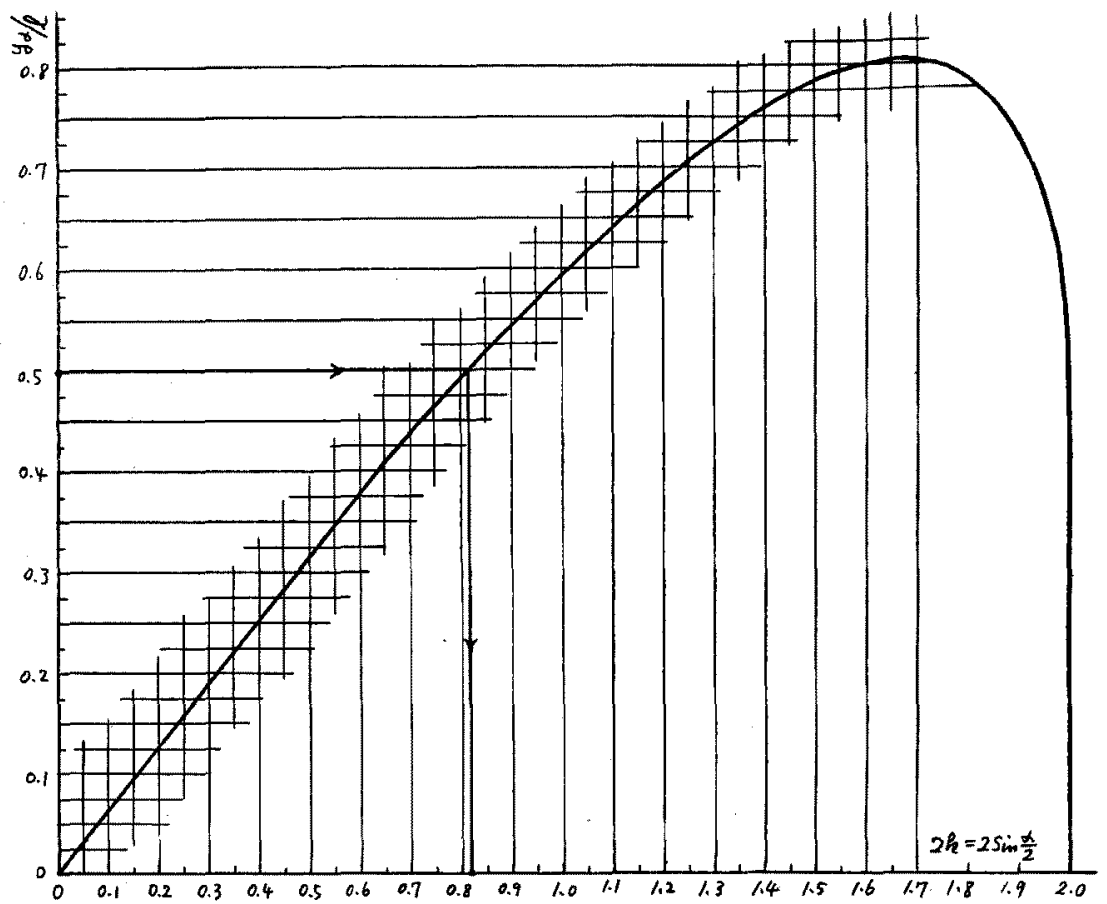

Fig. 2 Quasi-nomograph for horizontal method

$$
E I=\frac{P l^{2}}{\boldsymbol{F}(\pi / 2, k)}
$$

ここで $k=\sin \alpha / 2, \quad \boldsymbol{F}$ 第一種完全棈䧋皘分である。

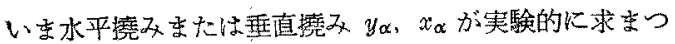
たとすると

$$
\begin{gathered}
-\frac{y_{\alpha}}{l}=\frac{2 k}{\boldsymbol{F}(\pi / 2, k)} \\
\frac{x_{\alpha}}{l}=\frac{2 \boldsymbol{E}(\pi / 2, k)}{\boldsymbol{F}(\pi / 2, k)}-1
\end{gathered}
$$

ここにEは第二種完全楕円積分である。 $y_{\alpha} / l, x_{\alpha} / l$ を実験 的に測定し， $k$ を求め，(1) に代入すると $E I$ が求まる。

さて $y_{\alpha} / l-k, x_{\alpha} / l-k$ の関係を因示すると Fig. 2, Fig. 3のごとくなる。しだつて（2）式よりも（3）式の方 が実用的には都合よいことがわかる。 $x_{\alpha} / l-k-\boldsymbol{F}(\boldsymbol{\pi} / 2$, k) の求め方はFig， 3 に示したごとく，图中の知印の方 向に順次たどればよい。なお式の誘導法については文末 に略述した。

奏験方法一試料を黑䤠りの板（幅 $5 \mathrm{~cm}$ 位）に $5 \mathrm{~mm}$

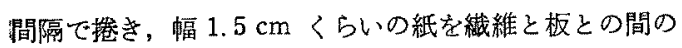
一方側の端に挿し込み，䋐維の上からセデープ淥のも のを貼つて固定し，クランプ端にする。他の側には䋞維 と板との間汇薄い錫䇠（幅 $3 \mathrm{~mm}$, 厚さ0. $2 \mathrm{~mm}$ ) を入れ. 䄉維の上から同様に細いセロテーブで固定する。クラン プ端と錫簿の中心間との距離は試料により調節すべをて 㐫る。21 den. 生落では $2 \mathrm{~cm}$ 前後が適当である。䄉維
のクリンプを除去するため，1〜数週間そのままの状態 (繁張状態)で恒温恒湿室に放置し，一種：mechanical conditioning をほどこした。

しかる後タランプ端を䋘維一本宛切りはなし，錫簿も

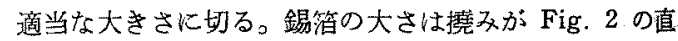

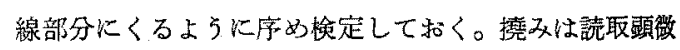
鏡で読めばよい。

Fig. 1-Bの上万な水平片持梁法に扎いても全く同じて ある。自重を無視してあるから垂直擢み $y_{\alpha}$ と自由端に 垂直に吊した荷重 $P^{\prime}$ を求めればよい。重直荷重 $P^{\prime}$ を水 平力 $P$ にな祘すと上の長柱法と全く同じになり（1）式 に $P=P^{\prime} \sin \alpha \cos \alpha$ を代入すればよいことになる。

第 1 表 21 中生系， $l=2 \mathrm{~cm}$

\begin{tabular}{c|c|c|c|c}
\hline & $P(\mathrm{mg})$ & $x_{\alpha}(\mathrm{cm})$ & $\boldsymbol{F}(\pi / 2, k)$ & $E I\left(\right.$ dyne $\left.\cdot \mathrm{cm}^{2}\right)$ \\
\hline 1 & 1.50 & 1.20 & 1.77 & 1.88 \\
2 & 1.95 & 1.10 & 1.79 & 2.39 \\
3 & 1.40 & 0.95 & 1.85 & 1.61 \\
4 & 1.45 & 1.02 & 1.82 & 1.72 \\
5 & 1.50 & 0.35 & 2.11 & 1.34 \\
6 & 1.50 & 0.81 & 1.89 & 1.66 \\
7 & 1.50 & 0.60 & 1.98 & 1.50 \\
8 & 1.75 & 1.80 & 1.61 & 2.55 \\
\hline mean & & & & 1.83 \\
\hline
\end{tabular}




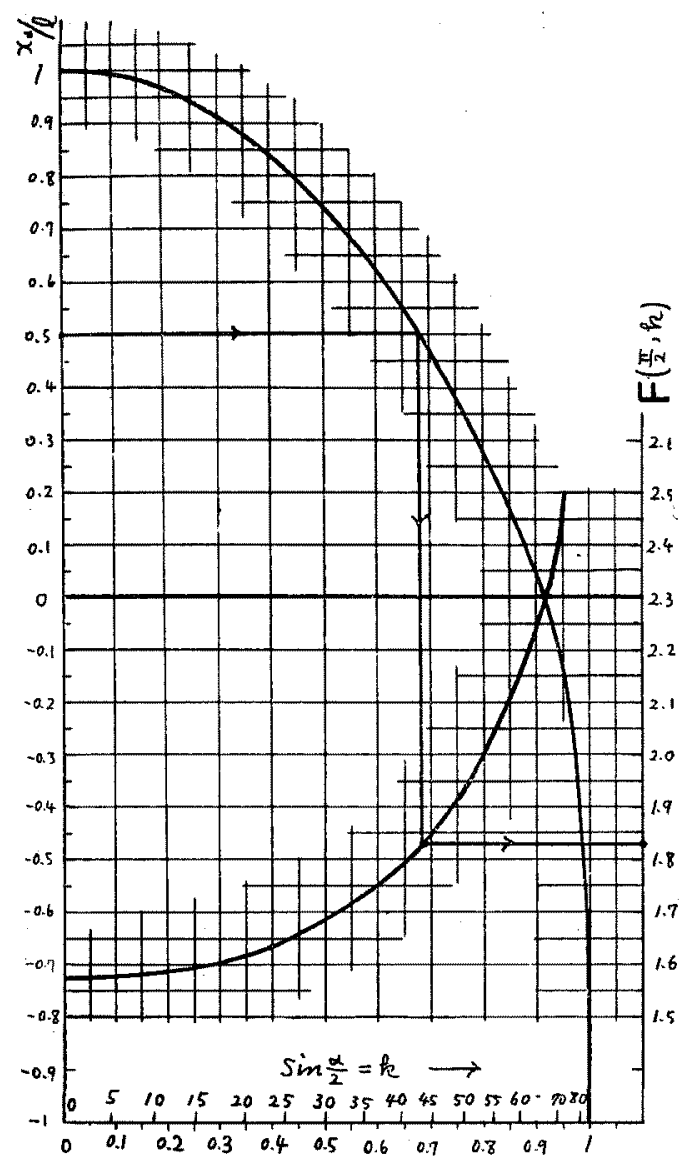

Fig. 3 Quasi-nomograph for vertical method

$$
E I=\frac{P^{\prime} l^{2} \sin \alpha \cos \alpha}{\{(\boldsymbol{F} \pi / 2, k)\}}
$$

したがつて(2)式から Fig. 2 を用いて求めることがで きる。第 1 表は長柱法により 21 中生系について求めた 一例でる。

この結果を他の方法により求めたものと比較する目的 で，次のループ法を用いた。本法は以下に詳述するごと く比較的細いるのにも利用できる。

(ii) ルーブ法 これは D. Sinclair ${ }^{10)}$ がガラス瀻維に 応用したもので，試料を Fig４４のようなキンク状のルー

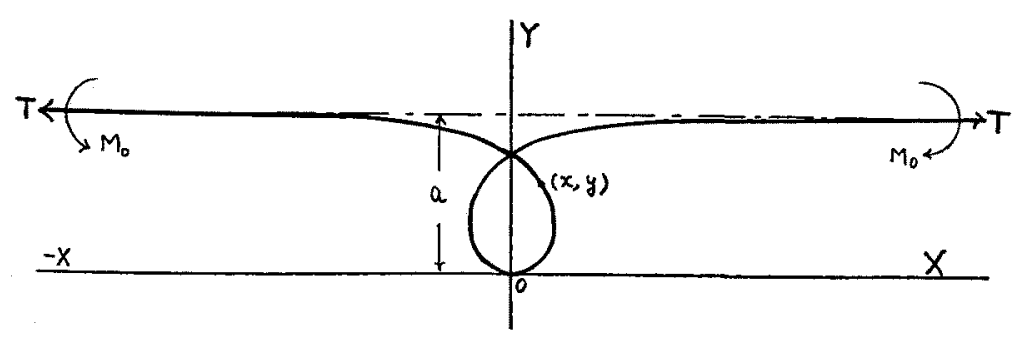

プKし, 張力 $T$ とループの高さ $a$ との関係

$$
E I=T / 4 \cdot a^{2}
$$

または

$\log T=\log 4 E I-2 \log a$

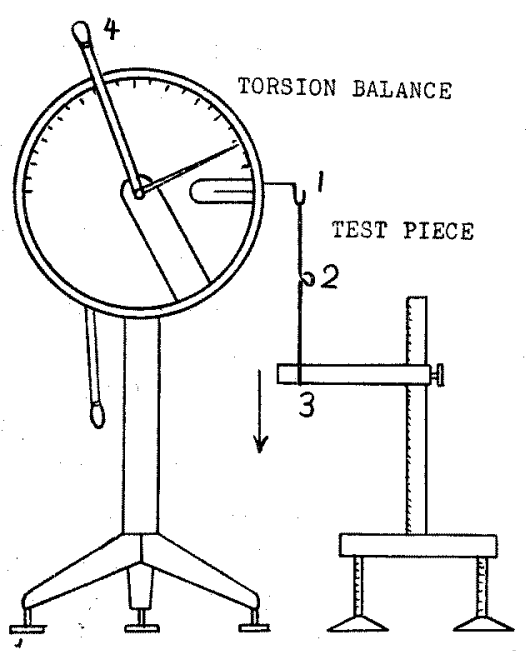

Fig. 5 Schematic diagram of an apparatus for loop method

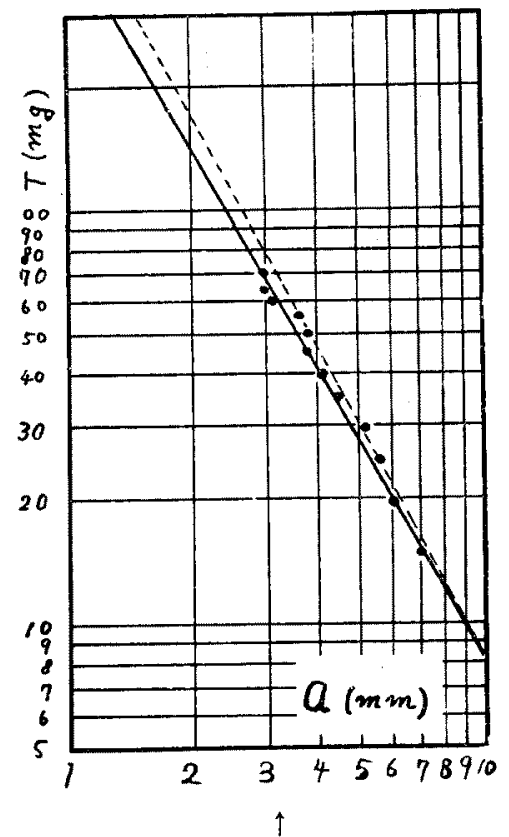

Fig. 6 T-S curve of $21 \mathrm{dem}$. raw silk, dotted line indicates (-2) gradient's

$\leftarrow$

Fig. 4 Principle showing loop method 
より，Tとaとを測定して $E I$ を求めることができる。 1'式から市かごとく，この閉係は対数グラフでは常に

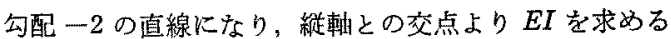
ことができる。

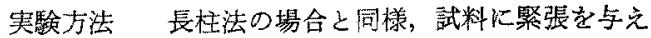
て十分コンディショニングし，ほとんど完全に真直くな 試料約 $15 \mathrm{~cm}$ 選び，一端をトーションバランスの荷重 鈎に結びつけ，一端を読取曊微鏡かカセトメーターに附 け，西值状態孛検定寸る。試料 2 の任ぼ中央にループを 作る。トーションバランスのアーム4を勳かして所要の 荷重量を定み，それにバランスするよ5に読取影徽鏡の テッタとピニオンを利用して 一プ径 $a$ を顕䃍製を用いて読を。張力 $T$ を徐々に大き

くし，それに伴つて いく。この場合試料にクリンプが残存している場合はそ れの效果が方るので，かかるデータは裹却した。

前記長柱法の場合と同じ試料を用いて害験した一例を Fig. 6 に示した。実駼範困は $T=10 \sim 150 \mathrm{mg}, a=10 \sim 2$ $\mathrm{mm}$ くらいであり，aの大きな場合には再現性のむるデ 一タは得られなかつた。なお式の誘尊法は Appendix に 示した。

(iii) 加撚法 6し試料に然（厳密には完全にセッ トされた塑性然なた双系の上万な安定撚）のある場合 には曲げ剛さとして相当曲げおよび据り留さ $B_{\hbar} ， C_{h}$ を 用いればよい，すなわり $n$ プライ撚の䒺では

$$
\begin{aligned}
& \left.\begin{array}{l}
B_{h}=n B_{0} \\
C_{n}=n C_{0}
\end{array}\right\} \\
& B_{0}=2 \sin \theta /\left\{\frac{1+\sin ^{2} \theta}{B}+\frac{\cos ^{2} \theta}{C}\right\} \\
& C_{0}=\sin \alpha /\left\{\frac{\cos ^{2} \alpha}{B}+\frac{\sin ^{2} \beta}{C}\right\} \\
& B=\sum_{j=0} m_{i} B_{s i}, \quad C=\sum_{j=0} m_{i} C_{s i} \\
& B_{s i}=2 \sin \beta_{i}\left\{\frac{1+\sin ^{2} \beta_{i}}{E I}+\frac{\cos ^{2} 1 \beta_{i}}{G I_{p}}\right\} \\
& C_{s i}=\sin \beta_{i} /\left\{\frac{\cos ^{2} \beta_{i}}{E I}+\frac{\sin ^{2} \beta_{i}}{G I_{p}}\right\}
\end{aligned}
$$

ここに

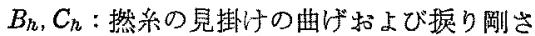

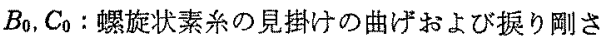

$B, C:$ 素糸の曲げ礼上び捻り剛さ

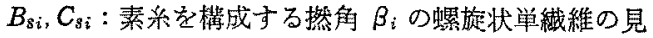
掛けの曲げおよび㹉り㴊さ

$E I, G I_{p}:$ 単䋊維の曲げおよび㨝り㓮さ

$\theta:$ プライ撚の撚角（檬軸となす角）

$\beta_{i}:$ 素糸の第 $i$ 層にるる単繊維の热角（横軸とな 主角)

$m_{i}:$ 素糸の第 $i$ 層にある単緎維の総数

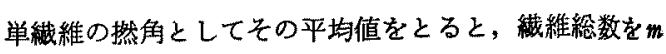
として

$$
\left.\begin{array}{c}
B=m B_{8}, \quad C=m C_{8} \\
\left.B_{s}=2 \sin \beta /\left\{\frac{1+\sin ^{2} \beta}{E I}+\frac{\cos ^{2} \beta}{G I_{p}}\right\}\right) \\
C_{8}=\sin \beta /\left\{\frac{\cos ^{2} \beta}{E I}+\frac{\sin ^{2} \beta}{G I_{p}}\right\}
\end{array}\right\}
$$

となる。一本撚の場合は $\theta=90^{\circ}$ となるから $B_{0}=B$ とな り, $\beta=90^{\circ}$ の場合は $B_{s i}=E I, C_{s i}=G I_{p}$ となるのは当 然である。

しかし上の式を適用するには续り実験を行つて挨り 用さを求め杖ならる久点があるが，一般には $\sin \theta=1$ $\cos ^{2} \fallingdotseq 0$ とみなせるから

$$
B_{0}=\frac{2 \sin \theta}{1+\sin ^{2} \theta} B
$$

となり，GIpの項を消去できる。さらに $\beta>0$ でるか ら同様にして

$$
E I=\frac{1+\sin ^{2} \theta}{4 m \sin \theta} \cdot B_{h}
$$

となる。

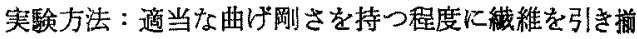
え，甘く然を加光試料緎維の中央部で折り曲げて热を戻 し，双然系を作る Fig.70よ5K撚が比較的強い場合に は先端に小さなループができるが，弱然の際には大きな ループになる。このループが大き過ぎると付加荷重とし

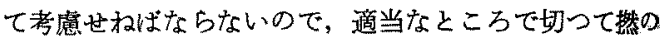

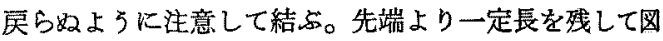
のごとく試料をボール紙仙はさんで怙で固定する。試料 長はその繊維の種類扣よび太さにより適宜に変党た方が 上い。100〜200den. のものなら $2 \sim 3 \mathrm{~cm}$ が適当である。

\section{3. 考察}

ルーブ法では $\log T-\log a$ 直線の勾配が試料に関保な くー2 となるはすであるが，Fig.6 に示したことく，得 られた直線は多少勾配が，-2 よりずれる㑯向を示して いる。この原因として考えられることは理論式からの背

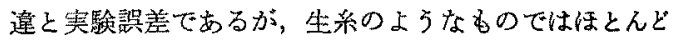
エシスティカと双なしても差し支免ないことが他の実験 からたしかかられている。また背異の傾向が一様性でな く前後には洼ジン゙ムに分布している点からも，これは 実験誤差とみなすべものと括もわれる。ループを作る には多少の熟練る要するが，ループさ交正確に作ればや や㬰験操作の煩雑なきらい性なるが長柱法より精度の高 い測定か゚期待できると括もわれる。

長柱法もループ法もエラスティカとしての基礎的原理 は全く同一のもので，単に境界条件のみが異るだけで るから，雨者の方法によつて得られた測定值もほほ同し 


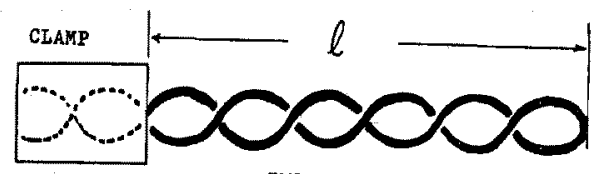

TWISTED SPECIMEN

Fig. 7 Schematic diagram of specimen for loop method

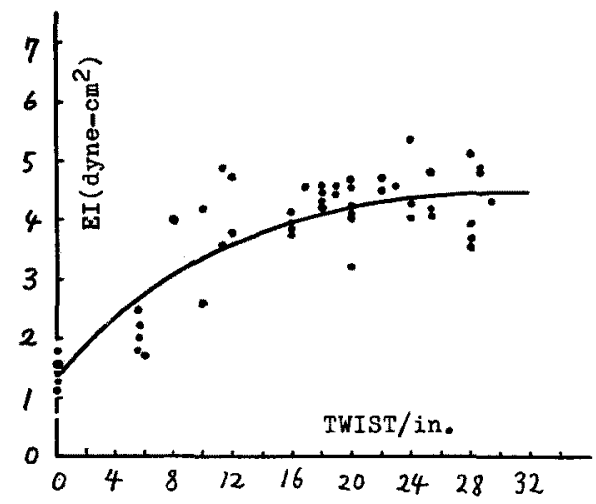

Fig. 8 Plots for EI of rawsilk vs. twist/in.

になることが予想され，実測の結果，長柱法とループ法 との間炕は得られた值の有意差がないことがわかつた。

Fig. 8 Kしめしたのは撚数とフィラメント1本の曲げ 剛さの関係であるこれからもわかる通り，単緘維 1 本に ついて測定した曲げ用さは集束加撚状態で測定したもの に比して，かなり小さな值を示しており撚が大きくなる に徒つて順次大さな值を示し, ある程度の大さに達する とはとんど平衡値に達する。21中生系の場合では集束状 態で測定したるのの方が 2 倍近くも大きくなつている。 その理由として考兄られることは次の二つである。

（1）各フィラメントまたはその一部が系の中心軸以 外の軸で曲げられている。すなわち断面二次モーメント が大きくなつている。このことは Steiner の定理によっ て示されることである。

（2）各フイラメント委たはとの一部が横圧々摩察力 とによつて接着し，全体が一本となつて挙動する。

以上の二つは本質的には全く同じ效果である。フィラ メントが完全にフリーな状態の場合には 1 本で測定した 結果と一致するはずであから減摩処理等により，かなり これ近すけることができるよらにおるわれる。したが つてフィラメント1本についての値を求める場合になる べく撚数を少なくし，フィヨメント間の相互作用を少な くさせるようにすればよい。

4. 釉括

（1）長柱（片持梁）法により㵶維または糸の曲げ剛 さを図的に求める方法を考察し，

（2）さらにエラスティカ法によるループ法により測 定した結果と此較し，両者により得られた数值間には差 がないことをみとめた。

（3）マルチフィラメントに加撚した状態で曲け゚剛さ を測定しそれより,フィラメント1本のそれを推定する 方法を導いた。

（4）それより各種撚数比打いて測定し，1本に対す る曲け゚㓮さが他の状態で1本について測定した結果より 大きくなることがわかつた。

（5）この原因はフィラムント間の相互作用によるる のと考えられる。これについて種々の原因を娭討した。

\section{5.あとがき}

本研究の一部は昭和 33 年度秋期 (大阪) ならびに昭和

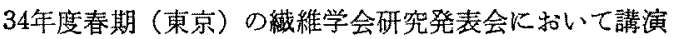
した。实験の一部は本学松橋房江氏の協力によるもので ある。な擆著の一人古平性現在旭化成工業株式会社高 規研究所に在籍している。

\section{Appendix 1 長柱法の解析法}

座標の原点を自由端(荷重端)にえらび，座標軸をFig. 1のようにとると

$$
E I \frac{d \theta}{d s}=-P y
$$

$s$ は試料の自由端からの距離である。 $d y / d x=\sin \theta$ であ るから

$$
E I \frac{d^{2} \theta}{d s^{2}}=-P \sin \theta
$$

両辺沉 $d \theta / d s$ を乗じて積分し， $(d \theta / d s)_{s=0}=0, \theta_{s=0}=\alpha$ な る条件を入れる，

$$
\begin{gathered}
E I \int d\left(\frac{d \theta}{d s}\right) \frac{d \theta}{d s}=-P \int \sin \theta d \theta \\
\frac{E I}{2}\left(\frac{d \theta}{d s}\right)^{2}=P(\cos \theta-\cos \alpha)
\end{gathered}
$$

$P / E I \equiv K^{2}$ と和くと

$$
d s=\frac{-d \theta}{K \sqrt{2} \sqrt{\cos \theta-\cos \alpha}}
$$

これを積分して全長 $l$ を求めると

$$
\begin{aligned}
l=\int \frac{d \theta}{K_{V} / 2 \sqrt{\cos \theta-\cos \alpha}} \\
\quad=\frac{1}{2 K} \int_{0}^{\alpha} \frac{d \theta}{\sqrt{\sin ^{2} \frac{\alpha}{2}-\sin ^{2} \frac{\theta}{2}}}
\end{aligned}
$$

$k=\sin \alpha / 2$ 々扣き， $\sin \theta / 2=k \sin \phi=\sin \alpha / 2 \cdot \sin \phi$ な る变数变換をすれば積分範围は $\theta(0, \alpha)$ から $\phi(0, \pi / 2)$ となる。したがつて

$$
d \theta=\frac{2 k \cos \phi d \phi}{\sqrt{1-k^{2} \sin ^{2} \phi}}
$$


これを（6）式に代入すると

$$
l=\frac{1}{K} \int_{0}^{\pi / 2} \frac{d \phi}{\sqrt{1-\bar{k}^{2} \sin ^{2} \phi}}=\frac{1}{K} \boldsymbol{F}\left(\frac{\pi}{2}, k\right)
$$

となる。Kに元の值を入れて変形寸札恃本交の (1) 式 が得られる。また $d y=d s \sin \theta$ に（5）式文代入すると

$$
d y=d s \sin \theta=\frac{-\sin \theta d \theta}{K \sqrt{2} \sqrt{\cos \theta-\cos \alpha}}
$$

となり,上端の水平方向の笁みは

$$
\begin{aligned}
& y_{a}=\frac{1}{2 K} \int_{0}^{a} \frac{\sin \theta d \theta}{\sqrt{\sin ^{2} \alpha / 2-\sin ^{2} \theta / 2}} \\
& =\frac{2 k}{K} \int_{0}^{\pi / 2} \sin \phi d \phi=\frac{2 k}{K}=2 k \sqrt{\frac{E I}{P}}
\end{aligned}
$$

(8)，(10) 式上り

$$
\frac{y_{\alpha}}{l}=\frac{2 k}{F\left(\frac{\pi}{2}, k\right)}
$$

同様にして垂直撓みは

$$
\begin{aligned}
x_{a} & =\frac{1}{2 K} \int_{0}^{a} \frac{\cos \theta}{\sqrt{\sin ^{2} \frac{\alpha}{2}-\sin ^{2} \frac{\theta}{2}}} d \theta \\
& =\frac{1}{K} \int_{0}^{\pi / 2} \frac{1-2 k^{2} \sin ^{2} \phi}{\sqrt{1-k^{2} \sin ^{2} \phi}} d \phi \\
& =\frac{1}{K}\left[2 \boldsymbol{E}\left(\frac{\pi}{2}, k\right)-\boldsymbol{F}\left(\frac{\pi}{2}, k\right)\right] \\
& \frac{x_{\alpha}}{l}=2 \frac{\boldsymbol{E}\left(\frac{\pi}{2}, k\right)}{\boldsymbol{F}\left(\frac{\pi}{2}, k\right)}-1
\end{aligned}
$$

\section{Appendix 2 ループ法の解析法}

Fig.4 からわかるごとくモーメントの釣合の式は

$$
M=M_{1}+T(a-y)=E I / \rho
$$

$\rho$ は曲率半径である。瀻維がループの曲率半径に比し† 分長い場合は $M_{1}$ は省略できるから

$$
\frac{1}{\rho}= \pm A \frac{d A / d y}{\left(1+A^{2}\right)^{3 / 2}}=b(a-y)
$$

ここに $A=d y / d x ， b=T / E I$ である。（16）式を積分す ると

$$
\pm \frac{1}{\sqrt{1+A^{2}}}=\frac{1}{2} b y^{2}-b a y+C
$$

$y^{\prime}{ }_{y=0}=0$ であるから正号で $c=1, y^{\prime} y=a=0$ となるから

$$
b=\frac{4}{a^{2}}
$$

となる。

$$
\text { 文 献 }
$$

1) 汁和一郎；人網界，8，191（1940）

2) 川上達也，池画栄雄；䋐工試瓷報 No. $32(1955-$ 3)

3）桜田一郎，迲和一郎；人絹界，7，882（1939）

4) F. H. Hummel \& W. B. Morton ; Phil. Mag., 4 348 (1927)

5) 高木春郎；私信

6）一志淑夫，内田貞夫；瀻畿誌，7，331（1954）

7) F. T. Peirce ; J.Text. Inst., 21, T 377 (1930)

8) W.G. Bickley ; Phil. Mag., 17, 603 (1934)

9) 哭路吉, 篠原昭; 末発表 (1959)

10) D. Sinclair; J.Appl. Phys., 21, 380 (1950). な扰類似の取报いをしたすのに（目的は同じではな (かが)

11) H.D. Conway; The nonlinear bending of thin circular rods, J.Appl. Mech., 23, 7 (1956) th ある。 